\title{
Literatura wojenna - szanse na powstanie syntezy
}

\section{Sławomir Buryła}

\section{Wprowadzenie}

Interesuje mnie pytanie o syntezę tematyki wojennej w literaturze współczesnej i najnowszej. Nie powstała dotąd praca, która by z rozmachem równym monumentalnej monografii Jerzego Święcha analizowała epikę, lirykę i dramat pod kątem obecności w nich problematyki „czasów pogardy" ${ }^{1}$. Nim przejdę do szczegółowych rozważań, poczynię ogólniejsze spostrzeżenia ważne dla kształtu przyszłej syntezy.

W refleksji nad II wojną światową od dwóch dekad dominuje dynamicznie rozwijający się namysł nad Szoah. Tematy polsko-żydowskie od momentu ukazania się Sąsiadów są przedmiotem licznych debat w radiu, telewizji, prasie i internecie ${ }^{2}$. Mniej więcej od tego czasu wydziela się też jako osobną literaturę Zagłady. W PRL tego nie czyniono, widząc w niej zapis martyrologii narodu polskiego. Obecnie refleksja nad problematyką Holokaustu stanowi autonomiczną dyscyplinę naukową. Jej odmienność, a zarazem rangę potwierdza synteza Literatura polska wobec Zagłady (1939-1968)3. Wypada przywołać jeszcze dwa inne ujęcia całościowe.

\footnotetext{
${ }^{1}$ J. Święch, Literatura polska w latach II wojny światowej, Warszawa 1997. Swoistym suplementem do tej monografii jest Nowy styl, nowe pióra. Antologia krytyki i eseistyki 1939-1945 (oprac. J. Święch, A. Wójtowicz, Lublin 2015). We wprowadzeniu zatytułowanym Wojna z bliska i z daleka czytamy: „W antologii naszej pragniemy zaoferować na wybranych przykładach całościowy obraz tego pisarstwa” (s. 10).

2 Zob. P. Forecki, Od „Sq̨siadów” do „Strachu”. Spory o polsko-żydowska przeszłość i pamięć w debatach publicznych, Poznań 2010.

${ }^{3}$ Literatura polska wobec Zagłady (1939-1968), red. S. Buryła, J. Leociak, D. Krawczyńska, Warszawa 2012. Aktualnie trwają prace nad kontynuacją tej publikacji. Od 2016 roku realizowany jest projekt grantowy Reprezentacje Zagłady w kulturze polskiej (1939-2015). W jego ramach pracuje kilkunastu badaczy z różnych dyscyplin naukowych. Zespołem kieruje prof. Sławomir Buryła. W niedługim czasie planowane jest rozpoczęcie prac nad kolejnym projektem będącym syntetycznym omówieniem tematyki Zagłady w piśmiennictwie polskim od roku 1968 do czasów obecnych.
} 
Obydwa ujawniają ambicje transdyscyplinarne. Następstwa zagłady Żydów. Polska 1944-2010 łączą bowiem perspektywę literaturoznawczą, historiograficzną, kulturoznawczą, politologiczną i socjologiczną ${ }^{4}$. Wydane zaś w 2017 roku Ślady Holokaustu w imaginarium kultury polskiej sięgają zarówno do dzieł z obszaru piśmiennictwa, jak i sztuk wizualnych ${ }^{5}$.

Wymienione powyżej opracowania naukowe, mimo że - z wyjątkiem Literatury polskiej wobec Zagłady (1939-1968) - nie spełniają wymogu stawianego klasycznej syntezie, dążącej do wyczerpania zagadnienia, jako takie nie mają swojego odpowiednika w badaniach nad piśmiennictwem powojennym dotyczącym „czasów pogardy”. Jedyne, czym dysponujemy w tym obszarze, to książki omawiające dorobek poszczególnych pisarzy albo - co o wiele rzadsze - ujmujące jakieś konwencje estetyczne z perspektywy większego odcinka czasu (jak choćby rozprawa Anny Sobolewskiej o psychologizmie $)^{6}$ lub prezentujące przekrojowo problemy i motywy związane z wydarzeniami z lat 1939-1945 (m.in. obraz Września 1939, walk o Westerplatte).

Spośród publikacji o charakterze syntetycznym wypadałoby jeszcze przywołać co najmniej trzy tomy zbiorowe. W latach siedemdziesiątych pojawiał się ważny tom Literatura wobec wojny i okupacji ${ }^{8}$. Prozie i poezji II wojny światowej nieco miejsca poświęcił Święch w Nowoczesności ${ }^{9}$. W 2011 roku ukazała się Wojna i postpamięć ${ }^{10}$. Spora część zawartych w niej szkiców dotyczy czasów pogardy widzianych przez pryzmat literatury europejskiej, a poszczególni autorzy koncentrują się nie tylko na źródłach piśmienniczych, ale też filmowych czy teatralnych.

Wspomniana na początku ekspansja badań nad poezją i prozą Zagłady przejawia się także w zawłaszczaniu niektórych obszarów doświadczenia wojennego. Tymczasem z łatwością znajdziemy zjawiska, które nie jest łatwo przypisać do jednego z dwóch obszarów - polskiego lub żydowskiego. Na trudności te wskazuje Arkadiusz Morawiec w monumentalnej monografii literatury lagrowej ${ }^{11}$. Jeśli w dobie PRL-u los Żydów w nazistowskich obozach stanowił fragment literatury lagrowej (a szerzej wojny i okupacji), to obecnie proza obozowa stała się „podgrupą” prozy Holokaustu.

Relacje polsko-żydowskie w imaginarium społecznym obejmują wiele punktów stycznych i konfliktowych zarazem. Należy do nich jeden z komponentów doświadczenia lagrowego - „pociąg śmierci”; dziś niemal automatycznie kojarzony z losem społeczności żydowskiej.

${ }^{4}$ Następstwa zagłady Żydów. Polska 1944-2010, red. F. Tych, M. Adamczyk-Garbowska, Lublin 2011.

${ }^{5}$ Ślady Holokaustu w imaginarium kultury polskiej, red. J. Kowalska-Leder, P. Dobrosielski, I. Kurz, M. Szpakowska, Warszawa 2017.

${ }^{6}$ Zob. m.in. A. Sobolewska, Polska proza psychologiczna (1945-1950), Wrocław 1979.

${ }^{7}$ S. Rogala, Echa września 1939 w polskiej prozie literackiej w latach 1945-1969, Kraków 1981; K. Zajączkowski, Literatura w procesie ksztattowania się miejsca pamięci po 1945 roku, [w:] tegoż, Westerplatte jako miejsce pamięci 19451989, Warszawa 2015. Dodajmy, że książka Rogali - z oczywistych powodów - nie obejmuje tekstów literackich, które pojawiły się w ciągu ostatnich czterech dekad. Ich liczba znaczenie wzrosła po roku 1989. Wrzesień domaga się nowej, aktualnej monografii naukowej. Pięć wybranych zagadnień przekrojowych (w tym tematykę lagrową, motywy wojenne w prozie pokolenia '56) omawiam w książce Rozrachunki z wojnq (Warszawa 2017).

${ }^{8}$ Literatura wobec wojny i okupacji, red. M. Głowiński, J. Sławiński, Wrocław 1976. Do najbardziej znanych szkiców z tego tomu należy Wojna i forma Marii Janion. Zob. też artykuły Janion poświęcone tematyce wojennej zgromadzone w książce Płacz generała. Eseje o wojnie, Warszawa 1998.

9 J. Święch, Nowoczesność. Szkice o literaturze polskiej XX wieku, Warszawa 2006.

${ }^{10}$ Wojna i postpamięć, red. Z. Majchrowski, W. Owczarski, Gdańsk 2011.

${ }^{11}$ A. Morawiec, Literatura w lagrze, lager w literaturze. Fakt - temat - metafora, Łódź 2009, s. 21. 
Tymczasem „pociągi śmierci” przywoziły na miejsce kaźni również nie-Żydów. Za sprawą choćby prac Raula Hilberga, Zygmunta Baumana czy Enza Traversa kolej stała się synekdochą „ciemnej strony” nowoczesności ${ }^{12}$. Wojciech Tomasik stwierdza: „Jeśli pomnikiem XIX stulecia, epoki pary i elektryczności, pozostanie parowóz, to stulecie następne, jakie przeszło do historii pod nazwą wieku totalitaryzmów, może być wyobrażone [...] w formie towarowego wagonu, którego stacją przeznaczenia był nazistowski obóz śmierci”13.

Niepojęte w swej skali deportacje ludności Europy Wschodniej były dziełem sowieckiej inżynierii społecznej. „Natychmiastowość” śmierci w nazistowskich obozach nie może nam przesłaniać rozłożonej zwykle w czasie eksterminacji całych narodów i klas społecznych. „Pociągi śmierci" służyły do przemieszczania olbrzymich mas ludzkich w komunistycznym ZSRR ${ }^{14}$. Zaświadcza o tym piśmiennictwo dotyczące sowieckich łagrów ${ }^{15}$.

\section{Kryzys syntezy}

Cechą współczesnej refleksji humanistycznej jest spojrzenie skoncentrowane na jednym tekście, postrzegające go jako obiekt samoistny i autonomiczny. To dziedzictwo po tradycji poststrukturalistycznej i postmodernistycznej. Podobnie jak oderwanie dzieła od kontekstu historycznego, społecznego, politycznego, co prowadzi do jego zubożenia - widzenia poza rzeczywistością, w której pisarz i - pośrednio - dzieło są zakotwiczeni. Literatura wojenna zaś - zwłaszcza ta oparta na doświadczeniu - czytana poza biografią autora traci znaczący kontekst interpretacyjny.

Z czego wynika kryzys syntezy? Decydują o tym czynniki różnej proweniencji. Wymieńmy niektóre z nich.

Nie ulega wątpliwości, że w przeciwieństwie do studiów z obszaru mikropoetyki, analizy dorobku poszczególnych twórców - finalizowana zazwyczaj w postaci klasycznej biografii naukowej ${ }^{16}$ praca nad ujęciem przekrojowym wymaga innego rodzaju kompetencji. Nie może się jej podjąć badacz będący na początku czy we wczesnej fazie swej drogi naukowej. Czasu, jaki należy poświęcić lekturze, nie da się zawęzić do kilku czy nawet kilkunastu lat. Potrzeba na to wieloletnich studiów.

Wielości literatury podmiotowej towarzyszy stale przyrastająca liczba prac podejmujących wybrane motywy wojenne w rodzimej prozie, poezji i dramacie. Pojawia się wątpliwość, czy dla tak

\footnotetext{
${ }^{12} Z$ ob. R. Hilberg, Zagłada Żydów europejskich, przeł. J. Giebułtowski, Warszawa 2014; Z. Bauman, Nowoczesność i Zagłada, przeł. T. Kunz, Kraków 2009; E. Traverso, Europejskie korzenie przemocy nazistowskiej, przeł.

A. Czarnacka, Warszawa 2001.

${ }^{13}$ W. Tomasik, Maszyna na wystawie. Szlakiem Tuwimowskiej „Lokomotywy”, [w:] tegoż, Ikona nowoczesności. Kolej w literaturze polskiej, Wrocław 2007, s. 235.

${ }^{14}$ T. Snyder, Skrwawione ziemie. Europa między Hitlerem a Stalinem, przeł. B. Pietrzyk, Warszawa 2015. Topos „pociągów śmierci” zwolennikom tezy o podobieństwie między stalinowskim komunizmem i nazizmem dostarczy jednego istotnego argumentu: dwa zbrodnicze systemy wykorzystywały zdobycze nowoczesnej techniki do realizacji swych ludobójczych praktyk.

${ }^{15}$ Dotychczas najpoważniejszym opracowaniem syntetycznym tej tematyki jest monografia Izabelli SariuszSkąpskiej Polscy świadkowie GUŁagu. Literatura łagrowa 1939-1989, wyd. 2, Kraków 2002.

${ }^{16} \mathrm{Na}$ temat różnych jej modeli zob. A. Całek, Biografia naukowa: od koncepcji do narracji. Interdyscyplinarność, teoria, metody badawcze, Kraków 2013.
} 
olbrzymiego materiału (z obszaru literatury podmiotowej i przedmiotowej), jaki należałoby poddać refleksji, nie powinno się powołać zespołu doświadczonych badaczy, z których każdy przygotowałby odpowiedni fragment $\mathrm{z}$ całości. $Z$ pewnością jest to rozwiązanie, które wypada brać pod uwagę przy tak rozległym zespole źródeł wymagających analizy. Warunkiem powodzenia rozległej syntezy jest współpraca grona naukowców obeznanych z piśmiennictwem źródłowymi, ale i opracowaniami historiograficznymi oraz literaturoznawczymi dotyczącymi II wojny światowej.

Niedostatek ujęć całościowych po części wynika również ze swoistej mody preferującej case study. Widać to nie tylko w literaturoznawstwie czy kulturoznawstwie, ale i w historiografii. Skupiamy się obecnie na mikrohistorii, a nie makrohistorii. Poza tym w metodologii historiografii - ale też literaturoznawstwa i kulturoznawstwa - następuje zwrot w stronę studiów nad zwierzętami, rzeczami, oral history ${ }^{17}$. Historia literatury sytuuje się w tle głównego nurtu zainteresowań.

Kryzys syntezy trzeba również łączyć ze zjawiskami zachodzącymi we współczesnej cywilizacji. Obserwujemy przecież od kilkudziesięciu lat wyraźny odwrót od refleksji w perspektywie „długiego trwania”, dominację prezentyzmu i podejścia ahistorycznego. Widać tendencję do myślenia poza kontekstami historycznymi i kulturowymi. Z pewnością jest to kolejne z pokłosie postmodernistycznej tezy o zmierzchu wielkich narracji. Terry Eagleton, mówiąc o przesunięciach w polach badawczych młodszych przedstawicieli nauk humanistycznych i społecznych, pisze z charakterystyczną dla siebie ironią:

Tym, co jest teraz sexy, jest seks. Na rozhukanych krańcach akademii zainteresowanie francuską filozofią ustąpiło miejsca fascynacji francuskimi pocałunkami. W niektórych kręgach kulturowych polityka masturbacji wzbudza znacznie większe zainteresowanie niż polityka Bliskiego Wschodu ${ }^{18}$.

Jeśli mimo to zgodzimy się, że synteza jest wciąż możliwa, interesująca dla czytelnika i potrzebna, powstaje pytanie dotyczące kompozycji. Może należałoby ją oprzeć na innych podstawach - na przykład na uporządkowaniu nie gatunkowym, wedle prądów czy grup literackich, a tematycznym. Wydaje się, że można zaproponować co najmniej kilka rodzajów uporządkowań tematycznych. Chcę się w tym miejscu upomnieć o jedno z nich. Chodzi o analizę pojęcia męskości w prozie i poezji o II wojnie światowej. Choć niewiele jest w kulturze koincydencji bardziej oczywistych niż męskość i wojna, dopiero niedawno powstała monografia odnosząca do siebie te dwa pojęcia ${ }^{19}$. Jej autor - Tomasz Tomasik - czyni to jednak tylko wobec tekstów pokolenia „Sztuki i Narodu”. Do omówienia pozostaje proza i poezja polska doby PRL.

${ }^{17}$ Zob. m.in. Teoria wiedzy o przeszłości na tle współczesnej humanistyki, red. E. Domańska, Poznań 2010.

${ }^{18}$ T. Eagleton, Polityka amnezji, [w:] tegoż, Koniec teorii, przeł. B. Kuźniarz, Warszawa 2012, s. 10.

${ }^{19}$ T. Tomasik, Wojna - męskość - literatura, Słupsk 2013. Prekursorska książka Tomasza Tomasika wskazuje na znaczący kontekst poznawczy dla badań nad doświadczeniem okupacyjnym i frontowym. Jest nią generacja akowska oraz czynniki, które ukształtowały tę formację. Mit młodzieży akowskiej domaga się zresztą konfrontacji z mitem „żydowskich Kolumbów”. Na płaszczyźnie symbolicznej „żydowscy Kolumbowie” odwoływali się do dni militarnej chwały narodu wybranego, a powstanie w getcie traktowali bardziej w kategoriach sprawdzianu męskości i przełamania stereotypów o wrodzonym tchórzostwie niż wiary w sukces militarny, jednocześnie ich biografie realizują niekiedy wzorcowe biografie młodzieży akowskiej. Pisałem o tym szerzej w szkicu Żydowscy Kolumbowie w książce Tematy (nie)opisane (Kraków 2013). Mówiąc o ujęciach syntetycznych kategorii męskości w kontekście wojny, trzeba odnotować najnowszą książkę Hegemonia i trauma Wojciecha Śmiei. Zob. W. Śmieja, Hegemonia i trauma. Literatura wobec dominującej fikcji męskości, Warszawa 2016. 
Autor przyszłej syntezy związków męskości i wojny musi odwołać się do lat 1918-1939. Ścieranie się światopoglądu militarystycznego i pacyfistycznego oddają Żołnierze Adolfa Rudnickiego. Józef Wróbel w Mierze cierpienia tak pisze o wymowie tej powieści:

Wojna ma być sprawdzianem i żołnierzy, i społeczeństwa, które pielęgnuje małe, niegroźne dla nikogo prócz jego samego mity, które nieświadomie gloryfikuje własną słabość, które fascynuje się tym, co pozorne - takie wnioski mógł wyciągnąć uważny i nieuprzedzony czytelnik. Trzeba będzie zapłacić za anachroniczne marzenia, za opóźnienie cywilizacyjne, za brak spójnej wizji narodu jako całości i za brak programu nowoczesnego wychowania jednostek i zbiorowości ${ }^{20}$.

Jednak dogłębna analiza musi sięgnąć jeszcze dalej - do tradycji sarmackiej i romantycznej. Żołnierz i konspirator z czasów pogardy był sukcesorem dawnego rycerza, sarmackiego wojownika, napoleońskiego i legionowego ułana, a w połowie lat trzydziestych awansował do rangi najważniejszej - propagandowo eksponowanej - figury męskiej identyfikacji tożsamościowej $^{21}$.

Synteza tematyczna jest zatem propozycją wartą przemyślenia. Musimy jednak mieć też świadomość możliwych niebezpieczeństw. Podstawowe jest następujące - odrzucając układ zgodny z chronologią powstawania poszczególnych tekstów, porzucamy zestaw najróżniejszych czynników politycznych warunkujących sposoby mówienia o wojnie w PRL. Oczywiście, możliwa jest też monografia tematyczna uwzględniająca porządek chronologiczny.

\section{Imaginarium społeczne}

W przypadku syntezy wojennej istotne jest określenie relacji między tekstem a imaginarium społecznym. Henryk Markiewicz wylicza możliwe punkty odniesień. Chodzi

[w pierwszym planie o] interpretację utworów literackich [...], oddziaływanie literatury jako tradycji na dalszy rozwój własny. Na planie dalszym, krzyżującym się z historią kultury literackiej pojawiają się tu takie problemy, jak: 1) społeczny zasięg i rozwarstwienie odbiorczej publiczności literackiej; 2) literackie sytuacje komunikacyjne i odpowiadające im instytucje; 3) czytelnicze motywacje i preferencje; 4) sposoby identyfikacji, interpretacji i wartościowania literatury; 5) pozycja i funkcjonalne odmiany odbioru literatury w całokształcie życiowej aktywności publiczności czytelniczej; 6) oddziaływanie literatury na inne dziedziny kultury symbolicznej; 7) przekształcenia, jakie powoduje ona w ideologii, mentalności i zachowaniu odbiorców ${ }^{22}$.

\footnotetext{
${ }^{20} \mathrm{~J}$. Wróbel, Miara cierpienia. O pisarstwie Adolfa Rudnickiego, Kraków 2004, s. 226.

${ }^{21} \mathrm{~W}$ formułowanych w latach trzydziestych programach wychowawczych - tych zalecanych do szkół oraz tych wywodzonych z literackiej tradycji - wyraźnie ujawniała się tendencja militarystyczna. Wartościowe wychowawczo okazywało się przede wszystkim to, co wyrastało z żołnierskiego dziedzictwa. Militaryzacja kultury oznaczała także jej maskulinizację (T. Tomasik, Wojna-męskość - literatura, s. 165-166). Rangę lat trzydziestych dla uformowania się zespołu autorytetów i wartości dobrze dokumentuje szkic Tomasika pt. Mitologia męskości w „Kamieniach na szaniec” Aleksandra Kamińskiego. Geneza tej powieści ma ideologiczny charakter. Badacz słusznie przypomina, że „[m]iała ona pełnić funkcję podręcznika młodego konspiratora i dywersanta, a po podziale Szarych Szeregów w listopadzie 1942 roku uznano ją za lekturę stosowną dla Bojowych Szkół, czyli harcerzy w wieku 15-17 lat zaangażowanych w mały sabotaż” (T. Tomasik, Wojna męskość - literatura, s. 214).

${ }^{22}$ H. Markiewicz, Dylematy historyka literatury, „Pamiętnik Literacki” 1986, nr 4, s. 19-20.
} 
Z punktu widzenia tematyki wojennej oraz jej wyjątkowego miejsca w świadomości społecznej za prymarne dla przyszłej monografii należy uznać punkty 4, 5, 6 i 7.

Nie trzeba nikogo przekonywać o fundamentalnym wpływie czasów pogardy na świadomość Polaków. Dwie znaczące monografie ostatniej dekady - Wielka trwoga Marcina Zaremby oraz Prześniona rewolucja Andrzeja Ledera - w pełni oddają rangę doświadczenia wojennego dla uformowania się sfery samoidentyfikacji i stereotypów. Pierwsza z nich analizuje znaczenie hitlerowskiej okupacji dla sfery moralności oraz mentalności, druga, nie bagatelizując tych obszarów, włącza je w zagadnienia awansu ekonomicznego i cywilizacyjnego ${ }^{23}$.

W połowie lat siedemdziesiątych Janusz Sławiński stwierdzał: „Wojna wstrząsnęła całym systemem naszej literatury; była przełomem, który poprzez swoje wielorakie skutki dzieje się jakby nadal w świadomości literackiej" ${ }^{24}$. Dopiero jednak dokładniejsza kwerenda pozwoliłaby doprecyzować odpowiedź i określić precyzyjnie krąg koniecznych analiz. O jakie zagadnienie tu chodzi? Dotyczy ono tego, co trzeba nazwać „śladami wojny w imaginarium kultury polskiej"25. Ślady Holokaustu w imaginarium kultury polskiej wskazują na charakter przyszłej pracy. Oto jak ich autorzy formułują zakres własnych poszukiwań:

Przepływ śladów Zagłady w polskim imaginarium biegnie nie tylko w kierunku tematów i zjawisk, które nie mają związku z Holokaustem jako wydarzeniem historycznym. Interesująca jest również ich cyrkulacja między różnymi formami i obiegami kultury, obejmującymi teksty literackie i naukowe, wypowiedzi publicystyczne, filmy i seriale, spektakle teatralne, nagrania oraz zdjęcia upubliczniane przez internautów, wpisy na portalach internetowych czy uliczne graffiti. Te zróżnicowane formy i media kultury interferują z różnorodnymi wspólnotami pamięci - rodzinnymi, rówieśniczymi, etnicznymi, religijnymi, klasowymi ${ }^{26}$.

Tak wytyczony obszar badań wobec tematyki wojennej jest niezwykle trudny do zrealizowania. Gdyby więc wzorem Śladów Holokaustu w imaginarium kultury polskiej przygotować publikację odnotowującą „ślady wojny”, to należałoby się zmierzyć ze znacznie bogatszym materiałem niż w przypadku Zagłady. Dokładnie mówiąc, prześledzenie wszystkich przedstawień wojny w teatrze, publicystyce, literaturze, filmie, kinie, bogatej sferze popkultury byłoby zadaniem nie tylko nader czasochłonnym, ale wręcz niewykonalnym. Celem winno być zatem odnotowanie (uwzględnienie w refleksji) nie wszystkich obrazów odsyłających wprost czy pośrednio do czasów pogardy, lecz tych najbardziej znaczących (choć nie zawsze artystycznie ciekawych), tych symptomatycznych; idzie o skonstruowanie mapy-przewodnika po literaturze, teatrze, filmie, kinie, kulturze popularnej dotykającej II wojny światowej ${ }^{27}$.

\footnotetext{
${ }^{23}$ M. Zaremba, Wielka trwoga. Polska 1944-1947. Ludowa reakcja na kryzys, Kraków 2012; A. Leder, Prześniona rewolucja. Ćwiczenia z logiki historycznej, Warszawa 2014.

${ }^{24} \mathrm{~J}$. Sławiński, Zaproszenie do tematu, [w:] Literatura wobec wojny i okupacji, red. M. Głowiński, J. Sławiński, Wrocław 1976, s. 15.

${ }^{25}$ „Imaginarium to nie tyle treści przekazów czy zawartość którejś z wielu zbiorowych pamięci, ile społeczne ramy określane za pomocą rozpoznawalnych znaków i praktyk, które dla użytkowników mogą nieść różne konotacje aksjologiczne i tożsamościowe". Tak definiują kategorię imaginarium autorzy Śladów Holokaustu w kulturze polskiej (s. 14).

${ }^{26}$ Tamże, s. 14.

${ }^{27}$ Oczywiście, topika wojenna pozostaje wciąż dla nas wyzwaniem, takim samym jak topika Holokaustu.
} 


\section{Kwestia datacji}

Jedna z wątpliwości, jakie muszą rozstrzygnąć autorzy przyszłej syntezy, dotyczy sprawy datacji. Kiedy rozpoczyna się powojenna historia literatury polskiej? Zazwyczaj w periodyzacjach historycznoliterackich przyjmowano rok 1945. Jednak coraz wyraźniej zaznacza się stanowisko tych, którzy wskazują na lato (lipiec) 1944 roku jako początek literatury współczesnej ${ }^{28}$. Dariusz Kulesza w studium Przełom? Lata 1944-1948 w literaturze polskiej przekonuje, że 1944 „wyznacza nie tylko początek polskiej literatury powojennej, ale także koniec literatury lat drugiej wojny światowej”29. Szukając specyfiki pisarstwa wojennego, powstającego hic et nunc, Kulesza wyjątkową rolę przyznaje generacji Kolumbów, akcentując odmienność ich dorobku artystycznego na tle przedstawicieli starszego pokolenia (dodajmy też, że nie bez znaczenia są tu też specyficzne biografie młodzieży akowskiej oraz autorów z kręgu „Sztuki i Narodu”). Pojawienie się i tragiczne odejście jego reprezentantów wyznacza początek, ale też koniec dramaturgii, prozy i poezji wojennej.

Można przywołać jeszcze jedną przesłankę na rzecz daty 1944. Teksty zrodzone i publikowane po przejściu frontu wschodniego, na terenach uwolnionych spod jarzma hitleryzmu, rodziły się w nowej rzeczywistości. Dałoby się wskazać wiele jej cech, ale prymarna jest sytuacja egzystencjalna pisarza tworzącego już w świecie po Katastrofie. Są to zatem przekazy utrwalane post factum, a nie hic et nunc, jak poezja Baczyńskiego czy Gajcego. Co nie pozostaje bez wpływu na kształt przekazu.

Kiedy wojna się kończy? Rzecz prosta, nie chodzi o uściślenia polityczne i rozstrzygnięcie starego sporu 8 czy 9 maja. Nie idzie też o znaną prawdę, że działania zbrojne faktycznie skończyły się na świecie 2 września 1945 roku - po podpisaniu aktu kapitulacji przez Japonię. Na płaszczyźnie prawdy psychologicznej, podobnie jak w dookolnym krajobrazie, zwłaszcza w okresie 1944/45-1948, wojna na ziemiach polskich ciągle trwała. Rzeczywistość wciąż przepełniała pożoga hitlerowskiej okupacji. Ludność nie czuła się wcale bezpieczniej ${ }^{30}$. W małych miejscowościach oraz wsiach grasowały bandy złodziei, rabusiów i kryminalistów. Po przejęciu władzy przez komunistów mieliśmy do czynienia z wojną domową. Do końca lat czterdziestych aktywność podziemia niepodległościowego była jeszcze duża. Oczekiwano wybuchu trzeciej wojny światowej (na nowo nadzieje te wzrosły wraz z konfliktem w Korei) ${ }^{31}$.

Keith Lowe, ukazując losy Europy w pierwszych kilkunastu miesiącach po wyzwoleniu, w znamienny sposób tytułuje swoją rozprawę - Dziki kontynent. Jak stwierdza, „historia Europy tuż po wojnie nie jest historią przede wszystkim odbudowy i uzdrowienia, lecz osuwania się w anarchię” ${ }^{2}$. Niestety, „nie istnieje książka, która by szczegółowo opisywała cały kontynent - Wschód i Zachód - w tym krytycznym i burzliwym okresie"33.

\footnotetext{
${ }^{28}$ Zob. T. Drewnowski, Próba scalenia. Obiegi - wzorce - style. Literatura polska 1944-1989, Warszawa 1997; S. Stabro, Literatura polska 1944-2002, Kraków 2002.

${ }^{29}$ D. Kulesza, Przełom? Lata 1944-1948 w literaturze polskiej, [w:] tegoż, Dwie prawdy. Zofia Kossak i Tadeusz Borowski wobec obrazu wojny w polskiej prozie lat 1944-1948, Białystok 2006, s. 349.

${ }^{30} Z$ Zob. np. zbiór reportaży M. Grzebałkowskiej, 1945. Wojna i pokój, Warszawa 2015.

${ }^{31}$ Zob. m.in. Z. Woźniczka, Trzecia wojna światowa w oczekiwaniach emigracji i podziemia w kraju w latach 19441953, Katowice 1999.

${ }^{32}$ K. Lowe, Dziki kontynent. Europa po II wojnie światowej, przeł. M.P. Jabłoński, Poznań 2013, s. 18.

${ }^{33}$ Tamże.
} 
Zapytajmy wprost: czy powojnie w Europie (czas od maja 1945) przynależy do historii literatury wojennej?

Uzgodnienie odpowiedzi na pytanie, kiedy wojna się kończy jest prymarne dla kanonu dzieł, które należałoby objąć refleksją. Czy winien się w nim znaleźć Popiół i diament Jerzego Andrzejewskiego? Albo czy należy uwzględnić teksty o dziejach żołnierzy niezłomnych i losy konspiracji niepodległościowej? Istnieje też grupa utworów, których akcja rozpoczyna się w czasach okupacji i trwa przez pierwsze lata po klęsce hitleryzmu. Wprowadzanie tu podziałów wynikających z granicy czasowej (8 maja 1945) byłoby czymś absurdalnym i naruszającym wewnętrzną spójność tekstu. Przywołajmy tylko Popielec Włodzimierza Kłaczyńskiego czy bardziej znanych Kolumbów. Rocznik 20. Romana Bratnego. W niektórych przypadkach takie postępowanie oznaczałoby usunięcie poza margines namysłu powieści wybitnych, tej rangi co Pierścionek z końskiego włosia Aleksandra Ścibora-Rylskiego ${ }^{34}$.

Czy jako appendix - a może jako fragment głównego nurtu narracji - winna się znaleźć w przyszłej syntezie opowieść o funkcjonujących od 1945 roku obozach koncentracyjnych, wykorzystywanych przez komunistów do prześladowania swoich wrogów politycznych oraz ludność niemiecką? Czy zatem należy uwzględniać takie publikacje jak reportaże Marka Łuszczyny Mała zbrodnia ${ }^{35}$ ?

Wreszcie, autorzy przyszłej monografii muszą postawić sobie pytanie o kryterium selekcji (poza aspektem czasowym). Jakie utwory należy brać pod uwagę? Czy jedynie te, w których obraz czasów pogardy wyznacza prymarny horyzont poznawczy, jest zasadniczym tematem? Czy uwzględniać również te dzieła, w których wojna stanowi główny motyw, ale nie jest on jedynym? Czy sięgać po te, w których odniesienia do hitleryzmu są ukryte pod maską paraboli, metafory?

\section{Wojna - cenzura - komunizm}

Namysł nad literaturą wojny i okupacji winien być wzbogacony o gruntowne kwerendy w Archiwum Akt Nowych w Warszawie. Do tych żmudnych i czasochłonnych poszukiwań przykładać należy wyjątkową wagę. Otwierają one bowiem przed nami szansę ujrzenia w pełniejszym świetle (z uwzględnieniem pełniejszego spektrum) artystycznych i ideowych artykulacji "epoki pieców”. Dokładne zapoznanie się ze zbiorami cenzury z pewnością wzbogaci naszą wiedzę o wojnie, pozwalając dostrzec tematy zakazane przez komunistyczny aparat represji ${ }^{36}$. Zasoby Głównego Urzędu Kontroli Prasy Publikacji i Widowisk zgromadzone w AAN pozostają olbrzymim wyzwaniem badawczym ${ }^{37}$. Wciąż nie znamy dokładniej ich zawartości. Wiemy bardzo niewiele o tym, w jakim stopniu oraz jakie teksty prozatorskie i poetyckie o II wojnie światowej zostały ocenzurowane - zatrzymane bądź „wyingerowane” przez pracowników GUKPPiW.

\footnotetext{
${ }^{34}$ A. Ścibor-Rylski, Pierścionek z końskiego włosia, Warszawa 1991.

${ }^{35}$ M. Łuszczyna, Mała zbrodnia. Polskie obozy koncentracyjne, Kraków 2017.

${ }^{36}$ Zob. m.in. K. Budrowska, Przeszłość ocenzurowana. GUKPPiW a obraz historii Polski w literaturze lat 1945-1958, [w:] tejże, Studia i szkice o cenzurze w Polsce Ludowej w latach 40. i 50. XX wieku, Warszawa 2014, s. 35-40.

${ }^{37}$ Zob. P. Krasoń, Akta Głównego Urzędu Kontroli Prasy, Publikacji i Widowisk w zasobie Archiwum Akt Nowych, [w:] Literatura w granicach prawa (XIX-XX w.), red. K. Budrowska, E. Dąbrowicz, M. Lul, Warszawa 2013.
} 
Zatrzymane przez cenzurę Kamili Budrowskiej to przewodnik po autorach i dziełach skazanych na niebyt ${ }^{38}$. Badaczka nie tylko referuje obowiązujące „na Mysiej” podejście do problematyki wojennej (drażliwej i niewygodnej z wielu względów dla cenzora), ale też ubogaca i na nowo wykreśla mapę powojennej literatury polskiej przełomu lat czterdziestych i pięćdziesiątych. Budrowska w swej monografii zamieszcza między innymi niedopuszczone do druku dramaty Rajmunda Hempla Dni grozy oraz Nadziei Druckiej Lamus. A przecież sprawa nie odnosi się tylko do tego czasu. Również w następnych dekadach dochodziło do konfiskaty tekstów dotyczących doświadczeń wojennych. Jak dotąd nie dysponujemy jednak dokładnymi danymi w tym względzie. Musimy też pamiętać, że o wiele większa niż liczba zatrzymanych była liczba dzieł „wyingerowanych”, czyli na różne sposoby poprawianych, zmienianych po zaleceniach i notkach z Mysiej.

Jak przekonuje Budrowska, badaczy literatury współczesnej nie tylko czeka niemała praca w archiwach. Do napisania pozostaje opowieść o niebyłej (takiej, której nie dano szansy narodzin/ zaistnienia) historii literatury polskiej. Nawet jeśli trudno spodziewać się arcydzieł, czy utworów wybitnych, zarekwirowanych przez cenzurę, to przecież nie można zaprzeczyć, iż ich konfiskata wpłynęła na charakter rozwoju polskiej poezji, prozy czy dramatu o tematyce wojennej. Budrowska stwierdza: „Zaprzepaszczoną szansą jest [...] poważne zahamowanie literatury poświęconej II wojnie światowej i Zagładzie"39. Nieco wcześniej słusznie wskazuje, że teksty te mogły „zapoczątkować nowe style, tematy, wprowadzić nowatorskie rozwiązania, może kogoś zainspirować”. Oczywiście, dziś niełatwo to wszystko oszacować, ale „straty [...] powetować się nie da - nie będą już nigdy skorelowane ze swoim czasem" ${ }^{40}$. A czy taką samą stratą - choć w innym wymiarze - nie są dzieła ocenzurowane, zmodyfikowane, okrojone. Jak wyglądałby dyskurs publiczny, gdyby dopuszczono je do druku w kształcie, jaki nadał im twórca. Jak wyglądałaby taka synteza historycznoliteracka. Z pewnością jej kodyfikatorzy musieliby postawić inne pytania, sformułować inne wątpliwości, niż to dziś czynimy na bazie tekstów „wyingerowanych” ${ }^{41}$.

Niemożliwe jest dziś powstanie syntezy tematyki wojennej bez prześledzenia zasobów GUKPPiW, jak i świadomości działania mechanizmów cenzury. Przyczyny polityczne sprawiały, że znaczna część doświadczenia okupacyjnego nie mogła stać się przedmiotem artystycznej artykulacji. Hanna Gosk, wyliczając „sfery milczenia” w piśmiennictwie PRL, konstatuje: „Wreszcie nie mieściły się $\mathrm{w}$ ramach powojennej wielkiej narracji o wojenno-okupacyjnym bohaterstwie i martyrologii Polaków niekoniecznie heroiczne, codzienne, egzystencjalne doświadczenia czasów pogardy, epoki pieców, spowszednienia zła, relatywizacji ról katów i ofiar, które próbował sygnalizować Tadeusz Borowski w opowiadaniach z tomu Pożegnanie z Mariq̨" ${ }^{42}$.

Osobnym zagadnieniem jest autocenzura, wynikająca $z$ formułowanych wprost lub pośrednio niekiedy będących częścią powszechnej wiedzy - sugestii i zaleceń, jak należy mówić o relacjach

\footnotetext{
${ }^{38} \mathrm{~K}$. Budrowska, Zatrzymane przez cenzurę. Inedita z połowy wieku XX, Warszawa 2013.

${ }^{39}$ Tamże, s. 115.

${ }^{40}$ Tamże.

${ }^{41}$ Zob. M. Fik, Cenzor jako współautor, [w:] Literatura i władza, red. E. Sarnowska-Temeriusz, Warszawa 1996.

${ }^{42} \mathrm{H}$. Gosk, Co wiedziała proza lat 40. XX wieku?, [w:] PRL - świat (nie)przedstawiony, red. A. Czyżak, J. Galant, M. Jaworski, Poznań 2010, s. 234.
} 
polsko-niemieckich, polsko-żydowskich, polsko-rosyjskich czy polsko-ukraińskich ${ }^{43}$. Bardzo trudno (jeśli w ogóle to możliwe) rozstrzygnąć, na ile sądy artysty stanowiły rezultat jego autentycznych przekonań, a na ile są nieświadomym efektem znajomości tego, co wolno, a czego nie wolno.

Kwestia komunistycznej cenzury pośrednio wskazuje na problem archiwów pisarzy. Są one w różnym stopniu rozpoznane i w różnym stopniu „wyeksploatowane”. W przypadku autorów uznanych, popularnych, nagradzanych zazwyczaj bardzo niewiele jest tekstów, które nie ukazały się drukiem. Istnieje wszakże niemałe grono twórców mniej znanych albo zapoznanych, których spuścizna nie jest dziś przedmiotem zainteresowania badaczy ani wydawców. Nie wiemy, co dokładnie zawierają pozostawione przez nich rękopisy i maszynopisy. Przygotowując syntezę historycznoliteracką, należałoby zatem zgromadzić dostępne informacje o zasobach archiwów poszczególnych autorów, tekstach niewydanych, a dostępnych w spadku po danym artyście.

\section{Powroty do wojennego czasu}

Toczący się od lat spór publicystyczny wokół okupacji oraz powojnia - angażujący również znaczną część społeczeństwa - nie przekłada się na liczebność tekstów naukowych. Albo inaczej, przekłada się nierównomiernie. Osiągnięcia historiografii polskiej taktującej o II wojnie światowej znacznie przewyższają osiągnięcia w tej dziedzinie kulturoznawców i literaturoznawców.

Na kilka sposobów trzeba dziś wracać do problematyki wojny i okupacji. Można - drogą żmudnej kwerendy - przybliżać i analizować teksty mniej znane albo podejmować tematy jeszcze nieopisane, problemy słabo rozpoznane. Można sięgać po nowe metodologie (wzorem mogą być badacze z obszaru Holocaust studies od lat aplikujący nowe propozycje intelektualne do refleksji nad Zagładą) $)^{44}$. Przykładając je do dzieł i autorów znanych, niemal emblematycznych, jak i zapomnianych można wydobywać z nich kwestie do tej pory nieporuszane. Nowe metodologie to nowe spojrzenie na utwory niekiedy zasklepione interpretacyjnie.

Powroty do wojny muszą się jednak łączyć ze świadomością przemian zarówno w samym widzeniu przeszłości, jak i charakteru współczesnej wojny. Święch poddaje pod rozwagę fakt rzutujący na kształt przyszłego ujęcia monograficznego. Wynika on z nowego typu wojny. Obecnie bowiem

inaczej niż to bywało kiedyś, wojna straciła jakby swoją dawną, niejako przypisaną sobie od zawsze ideę, jakąś myśl porządkującą, nadającą jej sens, skoro teraz jawi się jako zjawisko z gruntu nieprzedstawialne i niepojmowalne. W pierwszym przypadku myślimy po prostu o tym, że wśród dzisiejszych wyobrażeń wojny trudno znaleźć takie, które pozwoliłoby odtworzyć jej obraz całościowy, niepodobna bowiem podać przykładu, który byłby dla niej dostatecznie reprezentatywny. Zawsze będą to obrazy cząstkowe, niepełne ${ }^{45}$.

Nie jest to argument przeciwko zasadności powstawania syntezy, ani za nieprzedstawialnością doświadczenia okupacyjnego czy obozowego. Raczej wskazuje on na konieczność uświadomienia

${ }^{43} \mathrm{O}$ autocenzurze zob. m.in. K. Budrowska, Literatura i pisarze wobec cenzury PRL 1948-1958, Białystok 2009.

${ }^{44}$ Bodaj najnowszym nurtem w rodzimej refleksji holokaustowej są animal studies. Zob. P. Krupiński, „Dlaczego gęsi krzyczały?”. Zwierzęta i Zagłada w literaturze polskiej XX i XXI wieku, Warszawa 2016.

${ }^{45} \mathrm{~J}$. Święch, Nowoczesność, s. 192-193. 
sobie czynników modyfikujących spojrzenie holistyczne. Obecnie czasy pogardy za sprawą cywilizacji medialnej jawią się nam jako chaotyczne, poszatkowane, nie podlegające racjonalizującemu dyskursowi (w prozie taki obraz okupacji znakomicie oddaje Czarny potok Leopolda Buczkowskiego). Monografia winna wprowadzić jakieś znamiona porządku w nieporządku.

Przywołajmy inne konsekwencje poznawcze dla syntezy, wynikające z rozwoju współczesnej humanistyki:

Coraz więcej zwolenników przysparza sobie dziś pogląd, wedle którego nie mamy bezpośredniego dostępu do przeszłości (tu: historycznoliterackiej i historycznokulturowej), a procesy recepcji nie tyle ją przesłaniają, ile stają się jej nośnikami i nosicielami; dzieła w nich właśnie funkcjonują, kształtują i rozwijają swe znaczenia ${ }^{46}$.

Oczywiście, jak przekonuje dalej badacz, nasz punkt widzenia przeszłości nie jest ani uprzywilejowany, ani jedyny. Nie o to jednak toczy się batalia, lecz o to, czy narracja o przeszłości jest możliwa - narracja scalająca, porządkująca.

Zasygnalizujmy na koniec pośród zmiennych modyfikujących naszą aktualną wizję wojny kilka związanych z dystansem czasowym dzielącym badacza od epoki pieców, jak i jego indywidualnego zaangażowania.

Tak jak w przypadku twórców sięgających po tematykę wojenną, tak i badaczy nie jest bez znaczenia, z jakiej perspektywy czasowej omawiamy wydarzenia z lat 1939-1945. By przywołać przykład najbardziej wyrazisty - inaczej patrzymy na wojnę w roku 1989, a inaczej widzieliśmy ją wcześniej. Obok przyrastającej liczby publikacji i odkrywania nowych faktów (albo ukazywania w nowym świetle spraw znanych), zmienia się nasze podejście do przeszłości zarówno w rezultacie toczonych dyskusji i sporów, jak i pojawiania się nowych metodologii we współczesnej humanistyce. Jest oczywiste, że ważny czynniki rzutujący na obraz wojny stanowi różnica generacyjna, a jeszcze bardziej fakt, czy czasy pogardy były częścią biograficznego doświadczenia badacza, czy urodził się on znacznie później i zagadnienia te - choć wstrząsające - są mu znane jedynie ze źródeł. Nie chodzi o to, że ma on z tego tytułu mniej do powiedzenia na zajmujący go temat, lecz o trudne do zweryfikowania, ale przecież realne naznaczenie wojną w przypadku jego starszych kolegów.

$\mathrm{Na}$ koniec uwaga metodologiczno-kompozycyjna. Mimo iż ma ona swoje wady, opowiadam się po stronie tradycyjnego modelu monografii, w przeciwieństwie do słownikowo-encyklopedycznego ${ }^{47}$. Po pierwsze, w przypadku syntezy wątków odnoszących się do II wojny światowej konieczna jest narracja osadzająca opowieść w kontekstach społeczno-politycznych; po drugie, konieczna jest refleksja o charakterze genetycznym, sytuująca tekst w przyczynowo-skutkowej perspektywie. Miałaby ona - z jednej strony - ukazywać dany utwór na tle innych (wcześniejszych), jak też - $\mathrm{z}$ drugiej strony - odsyłać do istniejącej lub powstającej tradycji mówienia o doświadczeniu wojennym.

\footnotetext{
${ }^{46}$ R. Nycz, Możliwa historia literatury, „Teksty Drugie” 2010, nr 5, s. 170.
}

${ }^{47}$ Tamże, s. 170. 
Jedna kwestia z poruszonych w tym szkicu nie podlega dyskusji. Nie negując potrzeby badań cząstkowych, należy upomnieć się o publikacje prezentujące holistycznie tematykę wojenną w rodzimej literaturze. Umieszczenie dzieła na osi czasu pozwala ujrzeć zarówno zagadnienia recepcji, jak i ewolucji sposobu mówienia o okresie wyznaczonym datami 1939-1945. Z kolei sąsiedztwo innych tekstów umożliwia dostrzeżenie - obszerniejszego niż jednostkowe spektrum użytych technik artystycznych, przebiegu ich ewolucji, kierunku dokonujących się zmian w wyobrażeniach na temat wojny. Czytanie przez pryzmat innych utworów umożliwia też zidentyfikowanie momentu powstania kolejnych konceptów myślowych i estetycznych. Dlatego też oglądane z perspektywy procesu historycznoliterackiego Kamienne niebo Jerzego Krzysztonia i Pamiętnik z powstania Mirona Białoszewskiego ujawnia prekursorskość powieści autora Obłędu w „cywilnym” spojrzeniu na powstanie warszawskie.

Perspektywa holistyczna stanowi również szansę dokonania przewartościowań w kanonie, innego rozłożenia akcentów: docenienia dzieł pomijanych albo w ogóle nieobecnych w świadomości czytelniczej, ale też krytycznego oglądu tekstów, które z różnych powodów stały na piedestale. Zdarza się bowiem, że dopiero po latach jesteśmy w stanie docenić utwory, które wcześniej były przemilczane czy to ze względów politycznych, czy interpretacyjnej bezradności profesjonalnych i nieprofesjonalnych odbiorców. Wszystkie te zagadnienia odsłonią przed nami tylko analizy wychodzące poza teren wyznaczony przez pojedynczy tekst i jego horyzont. 


\section{SŁOWA KLUCZOWE:}

literatura polska XX wieku

SYNTEZA

\section{ABstrakT:}

Autor szkicu prezentuje aktualny stan badań nad literaturą o II wojnie światowej. Ukazuje go na tle bogatej refleksji nad literaturą o Zagładzie. W swojej zasadniczej części analizuje szanse i warunki powstania syntezy monograficznej o polskiej poezji i prozie dotyczącej II wojny światowej. 


\section{II wojna światowa}

\section{NOTA O AUTORZE:}

Sławomir Buryła - absolwent UMK w Toruniu, profesor w Instytucie Polonistyki i Logopedii na Uniwersytecie Warmińsko-Mazurskim w Olsztynie. Zajmuje się literaturą współczesną, edytorstwem oraz kulturą popularną. Ostatnio wydał Wokół Zagłady (Universitas, 2016); <slawomirburyla@wp.pl>. 